\title{
SPACE-AGE DEVELOPMENTS IN DESERT RESEARCH
}

by

Farouk El-Baz

Space-age technology has provided new tools for geological studies of the world's desert landforms. These include orbital images and photographs, as well as various means of automated monitoring of meteorological parameters and other temporal changes. A better understanding of the deserts is essential not only to the proper utilization of one-fifth of the Earth's land area, but also to the interpretation of wind-blown features on the planet Mars.

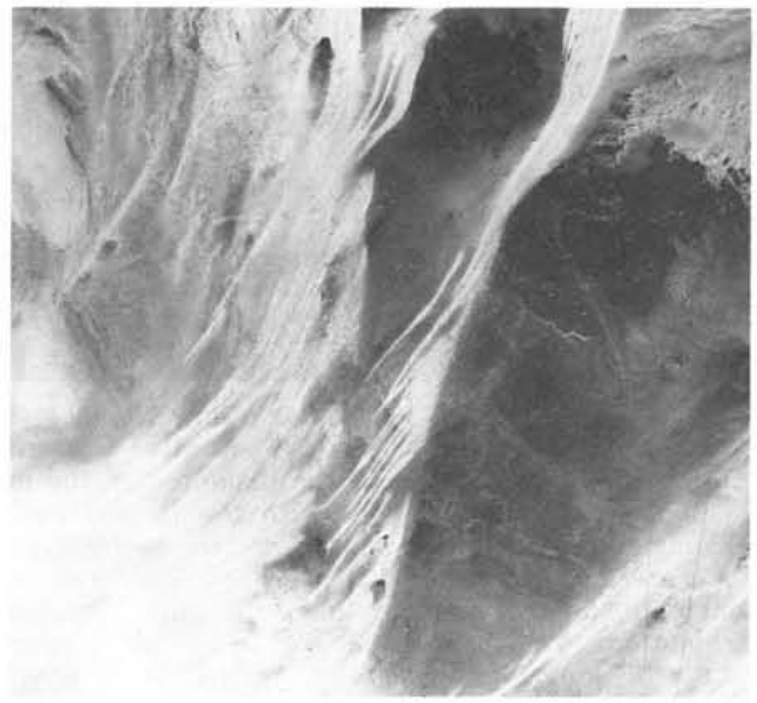

Landsat image of dune bundles whose orientations are affected by topographic highs such as the Uweinat Mountain (upper right) at the border intersection between Egypt, Libya and Sudan.

\section{Introduction}

The earth sciences had their origins in Europe - the only continent without a desert. Unlike mountain ranges, river basins and even glaciers, deserts and arid lands received little or no attention in the classical geological literature. In addition, by the very nature of their training, geologists looked for solid rock layers to decipher the history of the earth. Flat desert terrain covered by mixed rock rubble, sand and soil attracted only a handful of investigators. The immense size of most deserts also precluded their study by conventional means, particularly in view of the harsh conditions encountered in desert travel. As a result, deserts have remained the least understood of all of Earth's landforms.

A desert is usually defined as a land area that receives less than $25 \mathrm{~cm}$ of precipitation per year. It cannot, therefore, hold much vegetation and remains dry most of the time. This definition includes the so-called "cold deserts", which are regions characterized by perpetual ice and snow cover and intense cold. These regions include one-sixth of the landmass - over $23000000 \mathrm{~km}^{2}$. The term desert, however, is more commonly applied to the hot and dry regions of the earth, concentrated between $10^{\circ} \mathrm{N}$ and $40^{\circ} \mathrm{N}$ and between $20^{\circ} \mathrm{S}$ and $30^{\circ} \mathrm{S}$. These "hot deserts" or extremely arid lands constitute one-fifth of Earth's land area - nearly 31000000 $\mathrm{km}^{2}$.

In 1965 , when astronauts first observed and photographed the earth from orbit, they did not fully realize the enormous usefulness of this new vantage point. Because of their large areal coverage, orbital photographs were especially helpful in mapping regional patterns of sand distribution, studying large

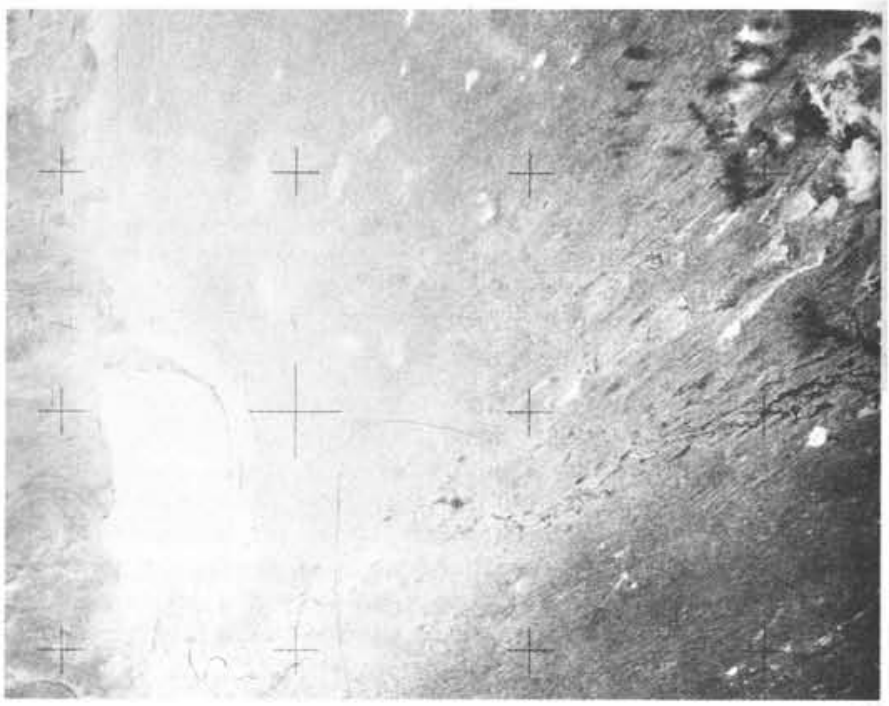

Apollo-Soyuz photograph of the Sturt Desert, Australia, showing the darkening (reddening) of dune sand as it is transported by the wind in a northeast direction away from the sand source - Lake Blanche - at lower left.

dune masses, and determining the direction of sand movement (McKee et al., 1977; El-Baz, 1977; McKee, 1979; Mainguet, 1978; El-Baz et al., 1980). The general lack of cloud cover over arid regions was found to improve image quality.

Because of the size, remoteness and inaccessibility of most deserts, preliminary reconnaissance surveys, including general descriptions of desert landforms and selection of areas for detailed fieldwork, could easily be made with orbital photographs. They clearly depict the colour variations of desert surfaces -indicative of changes in surface composition. They have also been used to confirm field observations of the red colour in desert sands. For example, in the Namib Desert of SW Africa, where linear dunes have migrated from west to east along the coast of Namibia, the sands farthest inland are older and much redder in colour (Logan, 1960).

Skylab 4 photographs of the same region show colour zones in the dune sand. Younger sands near the coast appear brighter than the redder zones farther inland (McKee et al., 1977). The Apollo-Soyuz photographs of southern Australia were used to illustrate dune reddening as a function of increasing distance from the source. For example, photographs of the Lake Blanche area in the Sturt Desert and of the Lake Eyre region in the southern Simpson Desert show an increase in red colour as the distance from the sand source increases (EIBaz, 1978).

This red colour has been attributed to the presence of hematite coatings on individual grains (see, for example, Walker, 1967), although the origin of the reddening remains 
controversial (Van Houten, 1973; Folk, 1976). The process of reddening has been reviewed by Walker (1967) and Glennie (1970). The variation in grain coating is significant because of its effects on the spectral signature of the sands on space images and photographs.

Recent studies indicate that the coating on sand grains is composed of kaolinite with powdery hematite, thus linking the reddening to desert varnish as described by Potter and Rossman (1977). Kaolinite in the coating is believed to originate as dust that percolates through the sand and adheres to the surfaces of the grains (Walker, 1979). Thus, the processes that result in the darkening of rock surfaces with time through the formation of desert varnish also act upon individual sand grains (El-Baz and Prestel, 1980). The clay component in the coatings of sand grains may be responsible for the creation of needle-like growths in sandstone oil reservoirs, which reduce their permeability (Güven et al., 1980).

While a number of desert regions are now being studied more closely, there is still a need for basic data on the desert environment, particulary in

Studies of climatic changes during the Quaternary: much like the layers of Antarctic ice, alternating layers of playas and eolian deposits in desert regions enclose a rich history of dateable changes in climate as far back as 200000 years (see Wendorf et al., 1976; Haynes, 1978). Recent publications on the topic include Butzer and Hansen, 1968, Al-Sayari and Zötl, 1978, and Horowitz, 1979.

Investigations of arid lands at the fringes of deserts: they constitute a fragile ecological environment which responds dramatically to external changes. A vivid example is the response of the sub-Saharan Sahel region during the relatively dry years from 1968 to 1973 (see proceedings of the U.N. Conference on Desertification, Nairobi, Kenya, 1977, El-Kassas, 1977, and Mainguet et al., 1979).

Studies of the feasibility of various economic development projects in the desert areas of less developed countries. Most nations in and around the major world deserts suffer from economic underdevelopment, growing populations and scarcity of food (Eckholm, 1976). Mismanagement of arid lands results from lack of a full understanding of the terrain and its characteristics (see Bishay and McGinnies, 1979).

Interpretation of the surface features of Mars as photographed by the Mariner and Viking spacecraft. Because of the contention that Mars harboured flowing water in its geological past, and the fact that eolian activity dominates the present Martian surface, much of Mars appears similar to many Earth deserts (Arvidson, 1972; McCauley, 1973; Mutch et al., 1976; El-Baz et al., 1979).

\section{Meteorological Monitoring}

In desert areas, meteorological monitoring stations are generally placed in oases which are located.in depressions, with surrounding cliffs exerting a great deal of influence on wind direction and its velocity. It has become apparent that they also need to be placed in open, inhospitable and inaccessible, arid, wind-blown terrain. Space-age technology has paved the way for this possibility.

Data collected by such automated stations can be transmitted to orbiting satellites, which then re-transmit the data to ground receiving stations for processing, distribution and analysis. Satellites which can receive and transmit data collected on the ground include Comsat, Intelsat, and the French Anik-type satellites.

At present, the U.S. Geological Survey is operating a program of remote monitoring of hydrologic data for water resources assessment (Paulson, 1978). Results of this program indicate both the cost-effectiveness of the method, and the advantages gained from realtime collection of data. In one case, improved estimates of runoff were instrumental in avoiding flood damage and generating extra electrical energy during the runoff period.

EPISODES, Vol. 1980, No. 4
Similarly, a meteorological data collection scheme may use Earth orbiting satellites to relay data from a great number of stations to one or more receiving stations. There are three basic elements to it: (1) a field radio, usually called a Data Collection Platform, that is connected to the sensor recorders; (2) a radio transponder with receiving and transmitting capability onboard a satellite; and (3) a data receiving station for retrieval, processing and dissemination to investigators. Programs currently using such a system in monitoring weather in remote places are located in Antarctica and in the southwestern U.S. deserts, representing two extremes of weather conditions.

The first is an Automatic Weather Station (AWS), which uses a transportable unit consisting of a three-meter triangular tower, environmental sensors, a data acquisition and radio transmitter unit, omni-directional antennae, and a power source. Located at Asgard Station, Antarctica, the AWS was designed by members of the Radioscience Laboratory at Stanford University (T. Howard, pers. comm.). In the near future, it will transmit sensor data to the "ARGOS" system aboard the TIROS-N satellite. The $400 \mathrm{Mhz}$ radio antennae, temperature sensor and wind speed/direction monitor sit on a horizontal spar on top of the tower. The microprocessorbased data acquisition unit, radio transmitter, and pressure sensor are housed in an insulated steel enclosure mounted at about the mid-level of the tower. Power for the AWS is supplied by either a radioactive thermo-electric generator (RTG) or by lithium batteries, the former having the capability to power the AWS for many years, the latter, as currently configured, can power it for more than two years.

The second program is that of the "Desert Winds" operated by the U.S. Geological Survey in Flagstaff, Arizona (J. McCauley, pers. comm.). In this case, stations consist of an aluminum free-standing tripod with a mast (extending approximately six meters) for mounting the wind sensors.

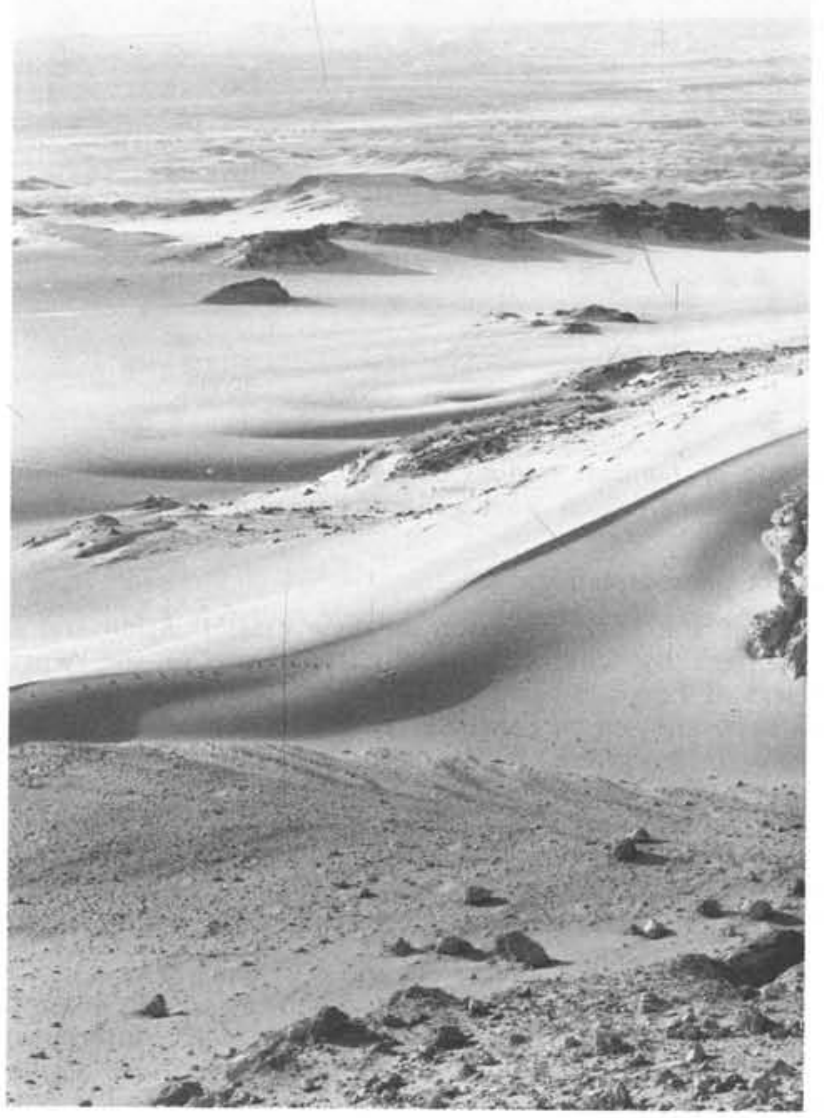

A descending dune at the scarp (to the right) of the Kharga depression in the Western Desert of Egypt. The wind regime within the depression is affected by the alignment of scarps and cliffs. 
Swiveling pads are provided with holes for securing the mast to the ground, and one leg is adjustable for leveling. A lockable steel enclosure houses the electronic equipment. The standard complement of sensors is made up of components to measure cumulative precipitation, wind speed with a time-weighted average, wind direction, temperature with vane aspirated radiation shield, relative humidity with sky shield, and barometric pressure.

The "Desert Winds" stations are powered by solar batteries. The only device that now needs to be added to such an array of sensors for desert monitoring is a dust particle counter which would help monitor the dust storms that plague desert regions. It would benefit aviation and other forms of strategic transportation in arid regions.

A program for remote monitoring of near-surface (up to $30 \mathrm{~m}$ ) meteorological information will help close the gap between orbital and Earth-based studies, particularly in investigations of both long- and short-term meteorological effects on areas prone to desertification. Although the data could be recorded in situ, the personnel, field support and time requirements would be prohibitively expensive. There would also be an extensive time lag between the acquisition and the use of data. Consequently, this new method of monitoring coupled with satellite relay is considered the only feasible way of gathering meteorological data on remote regions in a thorough and timely manner.

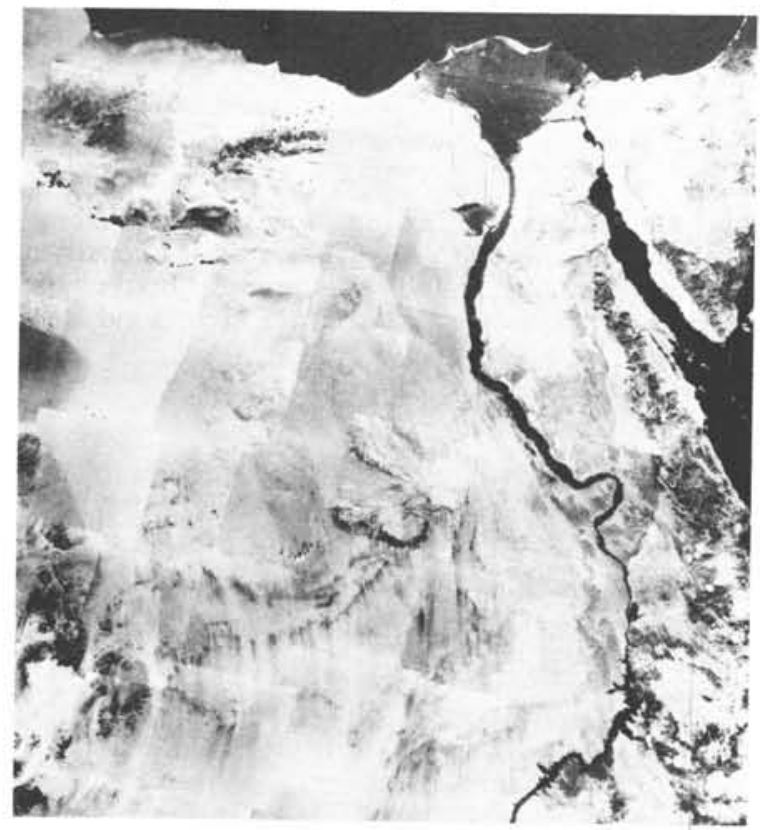

Mosaic of Landsat images of Egypt showing parallel lines of dune bundles, which move generally from north to south.

\section{Desert Geomorphology}

Much of the basic research on dune classification and sand movement by wind has been carried out in the Western Desert of Egypt, where "the free interplay of sand and wind has been allowed to continue for a vast period of time, and where, if anywhere, it should be possible in the future to discover the laws of sand movement and growth of dunes" (Bagnold, 1933, p. 121). Geomorphic descriptions followed by laboratory experiments led to Bagnold's (1941) classic treatise on the physics of sand movement by wind, based largely on observations made in the Western Desert of Egypt.

Research on desert landforms and arid lands was intensified during the past decade, partly due to the scientific interest in the effects of prolonged droughts in the Sahel. International and national research funding agencies are also starting to realize the importance of basic research work on the desert. As a result, we now have an impressive collection of books that treat the geomorphology of arid lands (Glennie, 1970; Mainguet, 1972; Cooke and Warren, 1973; Doehring, 1977; and Mabbutt, 1977).
Few geologists consider wind to be the major agent of sculpture in the desert, for many of the erosional landforms are "foreign" to geologists who are more familiar with the less arid regions of the world. Even the role of vorticity ir developing lineations by wind erosion was only recently accepted (Whitney, 1978), thus contradicting the hypothesis that changes in wind direction, with time, account for the orientation of ventifacts (Sharp, 1949, among others).



Ventifact, from the southeastern Western Desert of Egypt, showing the effects of negative and side wind flow, with a sand tail in the lee of the wind.

Wind erosion creates isolated hills; cliff retreat does not have to result from water erosion. Also, corrosion features, shaped solely by the wind can attain lengths of several hundred kilometers (Mainguet and Callot, 1978). Yardangs, the smaller wind-sculpted features that resemble inverted boat hulls, are being reported from numerous new localities, indicating new interest in wind-formed features.

Wind is also a very powerful agent of transportation. As the wind gusts in an arid environment, it hurls fine particles upwards as dust. Larger particles remain behind and form a protective armour of desert pavement on the surface. Midsized particles roll, bounce or saltate across the surface and accumulate to form dunes, which grow and modify their shapes as they succumb to changes in wind direction, and even breed dunes of the same kind. Some of the "offspring" are carried on the back of the "mother" dune. Others are borne downwind and move faster than the parent, keeping abreast of other offspring on the march.

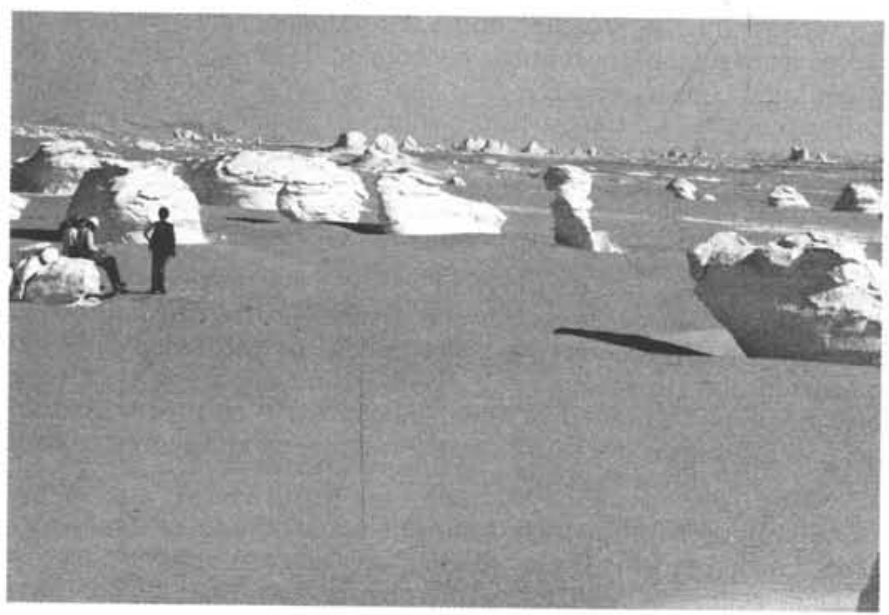

Wind-sculptured chalk blocks in a sand sheet within the Farafra depression in the central part of the Western Desert of Egypt.

The variety of dunes in the desert is staggering. Some are monstrous, uncrossable ones up to $200 \mathrm{~m}$ high and over $300 \mathrm{~km}$ long. Others are mere dwarfs only a few meters high. Where there is a limited supply of sand, coupled with a persistent wind, crescent-shaped or barchan dunes form. Groups of barchans meet to create complex patterns including doughnut-shaped dunes and irregular, crescentic 


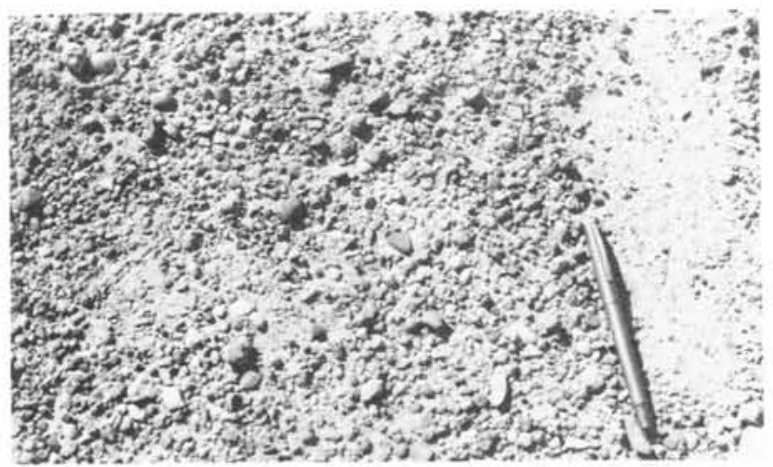

A coarse lag deposit, one pebble thick, which armors the desert surface in northern Sinai.

forms. If the wind changes directions drastically, it either forces the sand into numerous extensions to form star dunes, or keeps piling the sand into dome or pyramid dunes. Where there is a large supply of sand and persistent winds, linear dunes result. Crests of these meander in snake-like patterns. Groups of the linear dunes form many of the great sand seas of the Earth (Breed and Grow, 1979).

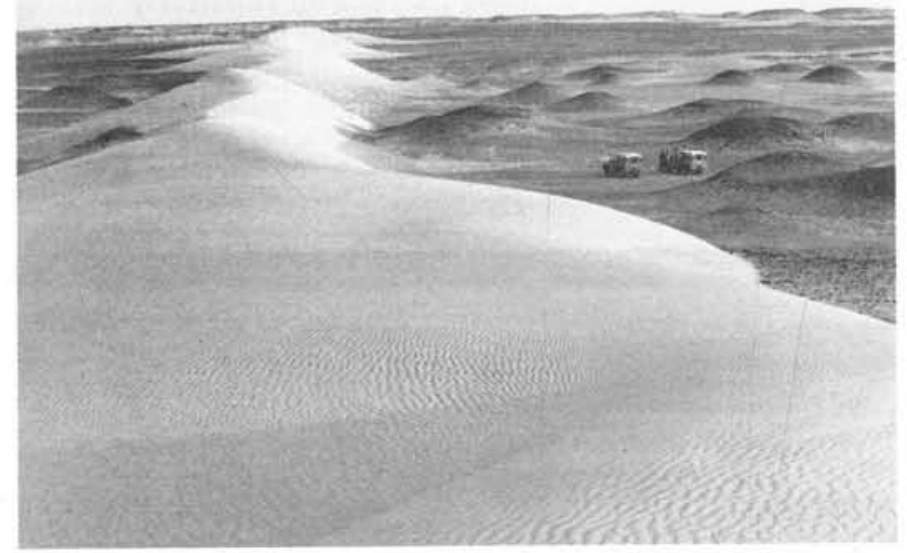

Linear dune in the lee of an escarpment in the Bahariya depression, Western Desert of Egypt.

\section{Human Habitation}

The term desert comes from the Latin verb "desero", to abandon. Thus "desertum" means abandoned, relinquished or forsaken - an exceedingly descriptive term, since most desert regions once hosted greater numbers and varieties of flora and fauna than they do today. When their weather conditions changed, these tracts were forsaken by the biota for other regions where life-sustaining water was more plentiful. The migration of humans was therefore affected as well.

Although soil erosion and salinization, as well as removal of the scant vegetation cover for firewood and grazing, represent grave problems to inhabitants of the deserts, the most formidable one is posed by the shifting sands. In dealing with them, one can either avoid them, try to halt their advance, or learn how to live with and use them. Avoidance of migrating dunes can be done by planning in advance. For example, if a dune belt is moving at the rate of $50 \mathrm{~m}$ per year, a settlement built at least $25 \mathrm{~km}$ farther downwind would exist without the danger of inundation for about 500 years.

To halt the advance of dunes, one can plant trees in their path. In the Sahara, oasis dwellers plant tamarisk trees for this purpose, though some farmers plant date palm trees instead. They serve as a physical barrier downwind, and are effective until the dune becomes tall enough to engulf the trees themselves. In Tunisia and Algeria, taller eucalyptus trees are being planted; these work as wind breakers rather than physical barriers. Their height (up to $100 \mathrm{~m}$ ) disturbs the wind regime, forcing the wind to unload the sand or limit grain transport before it approaches the wall of trees.

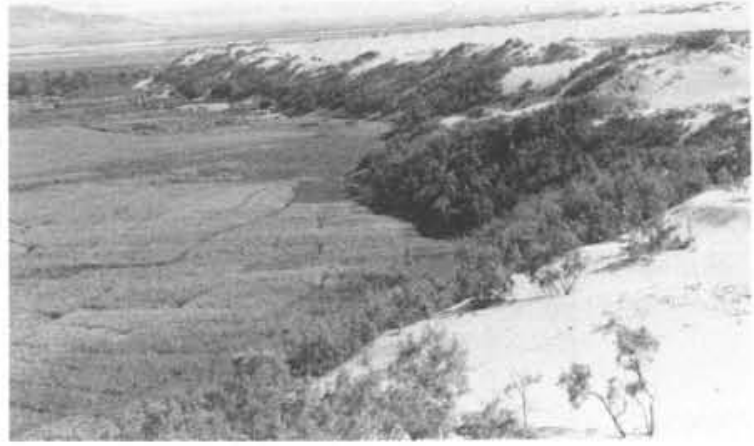

Tamarisk trees planted on the lee of an advancing dune, right, to halt its advance towards an agricultural field in Harra village, Bahariya Oasis, Western Desert of Egypt.

In India, parallel rows of dry hay fences, only $30 \mathrm{~cm}$ high, have been used to stabilize shifting dunes. In China, a checkerboard of hay fences divides the sand surface into $1 \mathrm{~m}^{2}$ areas. The fences are not designed to stop the motion of sand, but allow it to move within the one-meter squares.

Other methods include spraying them with petroleum as was successfully but expensively done in oil-rich countries like Iran and Saudi Arabia (Kerr and Nigra, 1952), or with chemicals such as "Sand Seal", a non-toxic water emulsified blend of liquid polymers and silicate derivatives. Stabilizing dunes by seeding them with grass is being done in southwestern, U.S.A., but this does not work in other deserts because of the scarcity of water and lack of humidity.

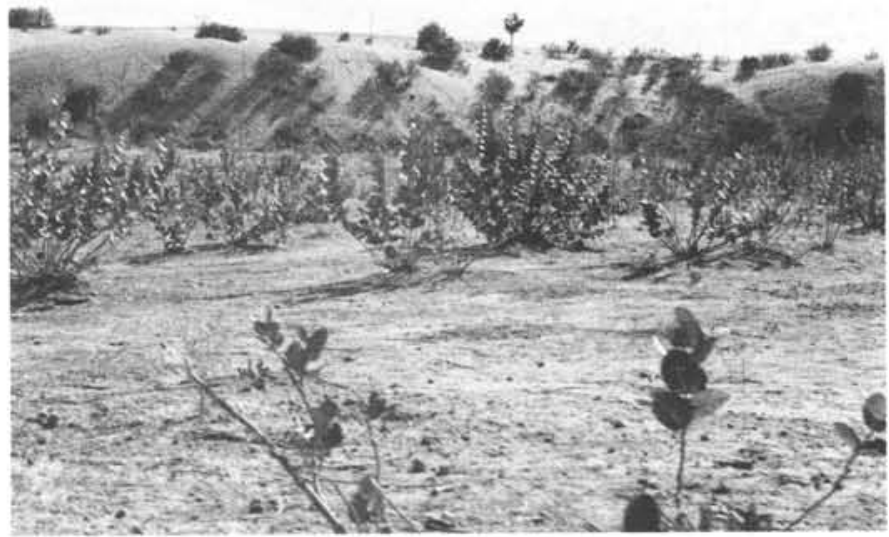

Dunes stabilized by natural vegetation near Bikaner in Rajasthan. NW India.

\section{Mars Analogies}

Exploration of the planet Mars during the past decade indicated that the seasonal variations in the reddish colour of the planet's surface are caused by meteorological effects. Mariner 9 and Viking 1 and 2 images show light-and dark-coloured streaks and splotches, the outlines of which have been ascribed to eolian activity (Veverka and Thomas, 1977). Furthermore, wind tunnel simulations confirmed that such features are the result of the transport of particulate material and the effects of topographic impediments on wind flow (Greeley et al., 1974).

Similar features are prevalent in Earth's deserts, particularly in the extremely arid parts. For example, both bright- and dark-tone wind streaks prevail in the southwestern part of the Western Desert of Egypt (El-Baz et al., 1979). Here, the bright streaks are composed of sand dunes and dune belts, sand sheets and lag deposits of light-coloured rocks, whereas the dark-toned streaks are predominantly locally derived desert pavement (El-Baz et al., 1980). Comparisons between such features shed additional light on eolian processes on both Earth and Mars. 


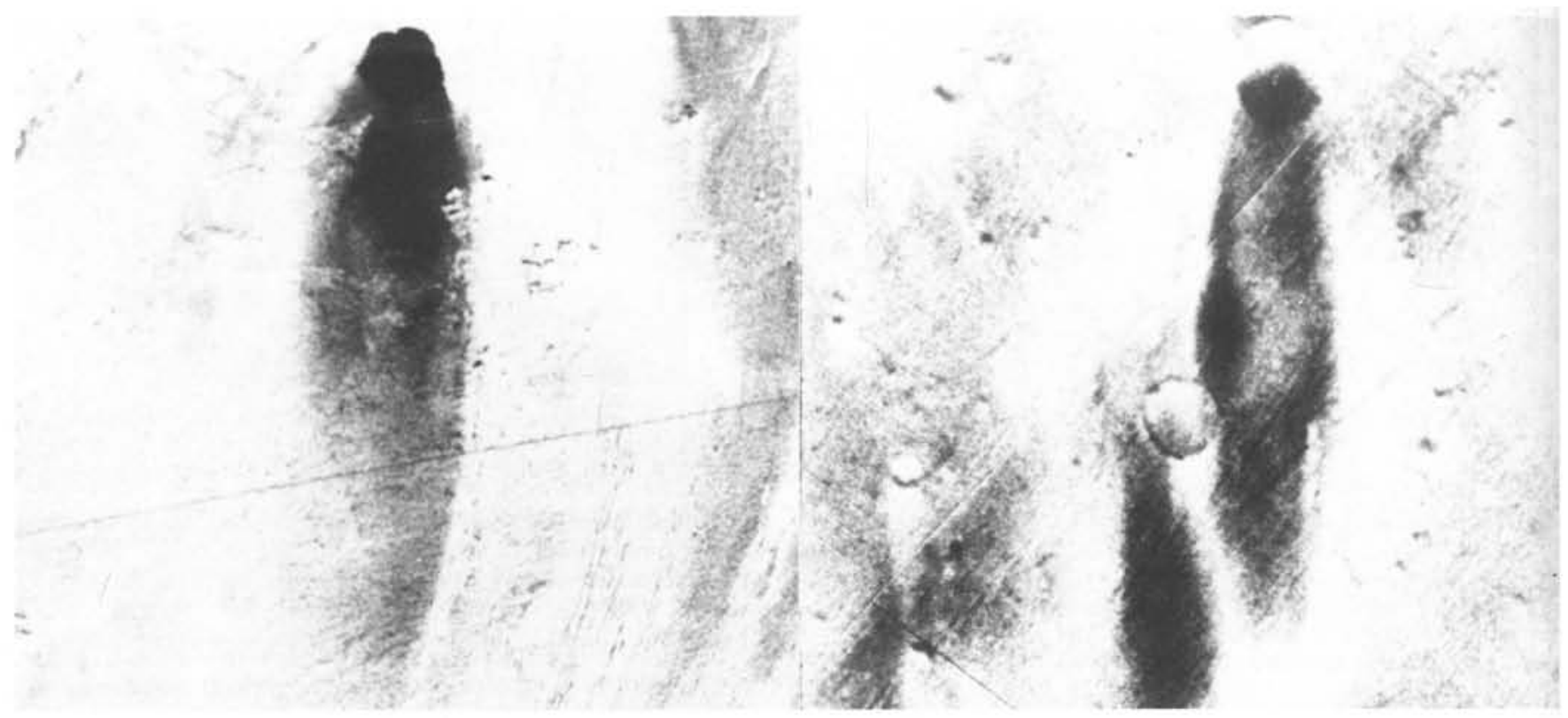

Spindle-shaped dark streaks in the lee of Hagar El-Garda hill, SE Libya, and of small craters in the Cerberus region of Mars, right. (Photos courtesy NASA)

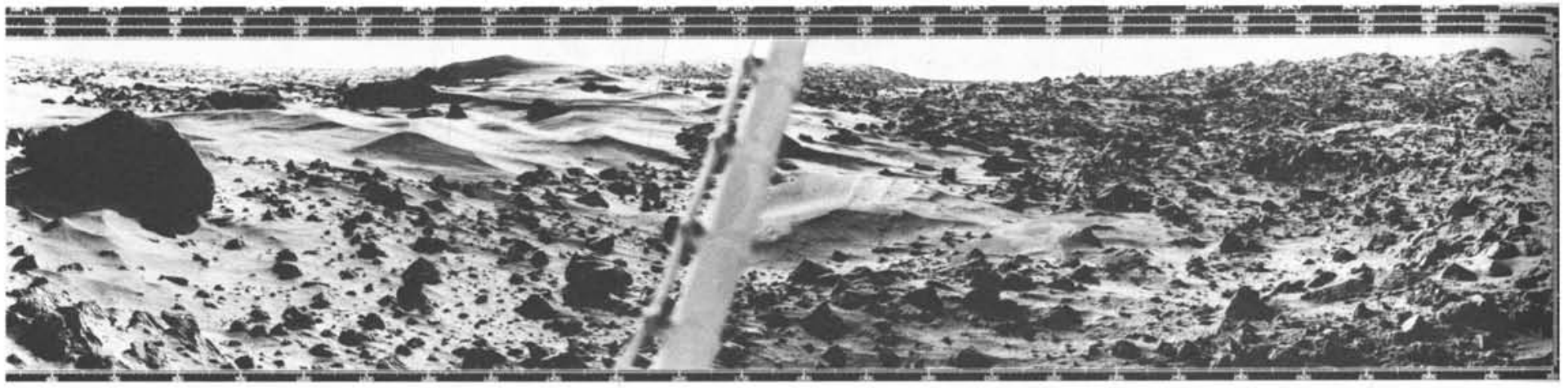

View of the Martian surface in the Viking l landing site showing sand drifts. The morphology indicates movement of the particulate material from left to right. The object in the middle of the photograph is part of spacecraft's meteorological monitor.

Dunes also abound on the Martian surface. In fact, the north polar region of Mars is girdled by the largest known individual dune field in the solar system. It is made of simple and complex crescent-shaped (barchan) dunes. Numerous erosional features are displayed on the Viking photographs, including isolated hills and yardangs, very similar to those in terrestrial deserts.

One interesting analogy was made recently between the rocks of southwestern Egypt and those in the Viking Lander sites. An expedition to the southwestern corner of Egypt (El-Baz et al., 1980) revealed an abundance of quartzite and basalt rocks, the outer surfaces of which had been pitted and fluted by wind erosion. These rocks bore a striking resemblence to those seen by the Viking Landers, generally interpreted as vesicular basalts. Wind tunnel studies on collected samples show that abrasion on windward surfaces coupled with negative flow, secondary flow and vorticity created the pits in the Egyptian samples (McCauley et al., 1979). Such field and laboratory observations suggested that the pits and flutes on the Martian rocks may also be formed by wind, and thus the Martian surface may be far more wind-eroded than previously thought.

EPISODES, Vol. 1980 , No. 4

\section{Future Research}

Detailed mapping and repeated monitoring of the earth's deserts would shed more light on the erosional forces of both Earth and Mars. The American Space Shuttle Program will collect new data and images for photogeologic and topographic analyses, through, for example, the use of the large format camera (LFC) to acquire mapping quality, stereo, 10$20 \mathrm{~m}$ resolution photographs on colour and/or black-and-white film. Such photographs will allow the compilation of or thophotomaps at 1:24000 scale, and provide the resolution necessary to make these into useful tools for the desert geologist. Monitoring temporal changes may be done via the repeated acquisition of multispectral images through the use of advanced satellites of the Landsat type and the French SPOT satellite scheduled to operate in the mid-1980's.

Desert geomorphology, emphasizing the use of space data, is being given due priority in many research organizations worldwide. For example, emphasis is placed on this topic by the U.S. Geological Survey's Center of Astrogeology at Flagstaff, Arizona, the Lanschow Institute of Desert Research in Lanschow, China, the Quaternary Geology, Geomorphology and Environmental Geology Division of the Geo- 


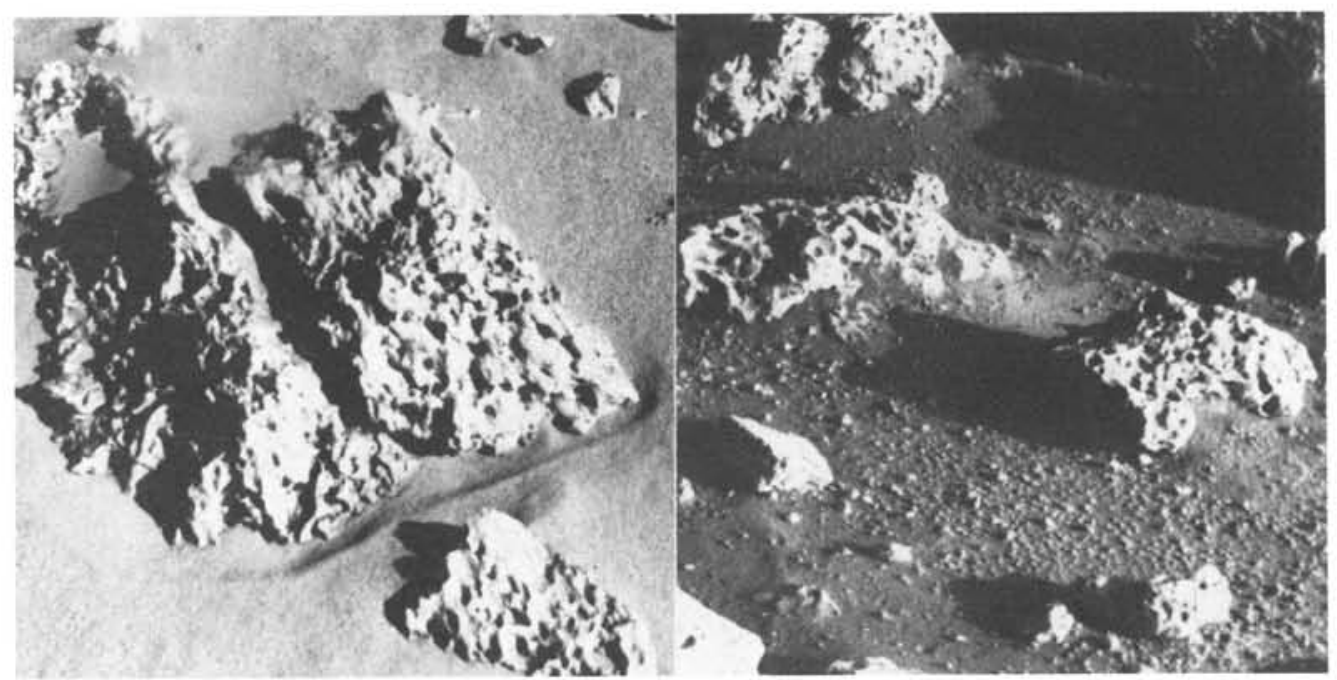

Left: photograph of wind-pitted quartzite rock in the Gilf Kebir region, SW Egypt. Right: Viking Lander 2 view of rocks strewn in its landing site.

logical Survey of India at Jaiput, and the Central Arid Zone Research Institute at Jodhput, India.

Realization of the importance of space data to desert research is resulting in nearly annual conferences on the topic. The subject was just covered during the November 1980 "Course on Physics of Flow in the Oceans, Atmosphere and
Deserts" held at the UN International Center for Theoretical Physics in Trieste, Italy. Also, the International Conference on Remote Sensing of the Environment will hold a "Symposium on Arid Lands", November 4-10, 1981 in Cairo, Egypt. Plans are now being drawn for a workshop on the arid land environment to be held a year later in the Rajasthan Desert, India, under the sponsor ship of the Smithsonian Institution.
References

Al-Sayari, S.S. and ZötI, J.G., (eds.), 1978, Quaternary period in Saudi Arabja: Springer-Verlag. New York. N.Y.

Arvidson, R.E., 1972, Aeolian processes on Mars: Erosive velocities, settling velocities and yellow clouds: Bull. Geol. Soc. America, v. 83, p. 1503 508.

Bagnold, R, A., 1933, A further journey through the Libyan Desert: Geogr. J., v. 82, p. 103-129.

Bagnold R.A.. 1941. The physics of blown sand and desert dunes: Methuen. London.

Bishay, A, and MeGinnies, W.G. (eds.), 1979, Advances in desert and arid land tectinology and development: Harwood Academic Publishers, New Yor N.Y.

Breed, C.S. and Grow, T., 1979. Morphology and distribution of dunes in sand seas observed by sensing, in McKee, E.D. (ed.), A study of global sand seas: Geol. Sur. Prof. Pap. 1052, P. 253-302.

Butzer, K.W. and Hansen. C.L., 1968, Desert and river in Nubia: The Univ. of Wisconsin Press, Madison. Wisconsin.

Cooke, R.U. and Warren, A., 1973, Geomorphology in deserts: University of California Press, Berkeley, Callifornia.

Doehring, D.O. (ed.), 1977, Geomarphology in arid regions: Annual Geomorphological Symp., Binghamton, N.Y., 8, 272 p.

Eckholm, E., 1976, Loosing ground: environmental stress and world

E1-Baz, F., 1977. Astronaut observations from the Apollo-Soyuz mission: Smithsonian Institution Press, Washington, D.C., 400 p.

El-Baz, F.. 1978, The meaning of desert color in Earth orbital photographs: Photogramm. Eng. Rem. Sens., v. 44, i, p. 69-75.

El-Baz, F., Breed, C.S., Grolier, M.J. and McCauley, 3.F., 1979. Eolian features in the Western Deser: of Egypt and some applications to Mars: I. Geophys, Res., Y, 84, P, 8205-8221.

El-Baz, F. and Prestel, D.J., 1980, Desert varnish on sand grains from the Western Desert of Egypt: Importance of the clay component and implic-
Lunar and Planetary Institute, Houston, Texas, p. 254-256.

El-Baz, F., Boulos, L., Breed, C., Dardir, A. Dowidar, H., El-Etr, H. Embabi, N., Grolier, M. Haynes, V., Ibrahim, M., Issawi, B., Maxwell, T. McCauley, J., McHugh, W., Moustafa, A. and Yousit. M. 1980, Journey to the Gilf Kebir and Yousinat, Southwest Egypt, 1978, Geogr. J.9 146, Part 1, p. 51-93.

4-Kassas, M., 1977, Are deserts man-made?; The UNESCO Cour ier, Paris, France, v. 30, p. 4-6.

Folk, R.L., 1976, Reddening of desert sands: Simpson Desert, N.T., Australia: 1. Sed. Petrol., v. 46, 3, p. 604-615.

Glennie, K.W., 1970. Desert sedimentary environments: Elsevier, New York, N.Y.

Greeley, R., Iverson, 3.D., Pollack, J.B., Udovich, N. and White, B., 1974, Wind tunnel simulations of light and dark streaks on Mars: Science, $\vee .183$. 4127 , p. $847-849$.

Gtiven, N., Hower, W.F. and Davies, D.K., 1980, Nature of authigenic illites in sandstone reservoirs: 3. Sed. Petrol.. v. 50, 3, p. 761-766.

Haynes, C.V., 1978, The Nubian Desert: A product of Quaternary climatic cycles (abstract): NASA 55, P. $22-23$.

Horowitz, A., 1979, The Quaternary of Israel: Academic Press, New York, N.Y.

Kerr. R.C. and Nigra, J.O., 1952, Eolian sand control: Bull. American Assoc. Petrol. Geol., v, 36, 8, P. 1541-1573.

Logan, R.F., 1960, The central Narnib Desert, Southwest Alrica: Nat, Acad. Sci., Nat, Res. Counc. Publ. 758, Washington, D.C.

Mabbutt, J.A., 1977, Desert landforms: The MIT Press, Cambridge, Mass.

McCauley, J.F., 1973, Mariner 9 evidence for wind erosion in the equatorial and mid-latitude regions of Mars: J. Geophys. Res., v, 78, 20, p. 4123-

McCauley, J.F., Breed, C.S, El-Baz, F., Whitney, M.I., Grolier, M.J., Ward, A.W., and Greeley, R. (ed5.), 1979, Pitted and fluted rocks in the Western Desert of Egypt: Viking comparisons: Geophys, Res., v. 84, B14, p. $8222-8232$.

McKee, E.D. (ed.), 1979, A study of global sand seas:
Geol. Surv. Prof. Pap. 1052, U.S. Gov. Printing Office, Washington, D.C.

McKee, E.D., Breed, C.S, and Fryberger, S.G., 1977. Desert sand seas, in Skylab Explores the Earth: NASA 5P-380, p. 5-47.

Mainguet, M., 1972, Le modèle des Grés: Probtèmes gener aux: Inst. Géograph. Nat., Paris, 2 y.

Mainguet, M. and Callot, Y., 1978, L'Erg de FachiBilma, Chad-Niger: Centre Nat. Res. Sci., Paris.

Mainguet, M., Cannon-Cossus, L. and Chemin. M.C. 1979, Dégradation dans les régions centrales de la Republique du Niger: Trav. Inst. Geogr. Reims, n. $39-40$, p. $61-73$.

Mutch, T.A., Arvidson, R.E., Head, J.W., Jones, K.L., and Saunders, R.S., 1976. The geology of Mars: Princeton Univ. Press, Princeton, New Jersey.

Paulson, R.W., 1978, Use of Earth satellites for automation of hydrologic data collection, in Collection, storage, retrieval. and publication of water resources data: U.S. Geol. Surv. Circ. 756, p. 8-14.

Potter, R.M. and Rossman. G.R., 1977. Deser: varnish: mineralogy of the ferromanganese oxides: Eos, v. 58, 12, p. 1242 .

Sharp, R.P. 1949, Pleistocene ventifacts east of the Big Horn Mountains, Wyorning: J. Geol., v. 57, 2 , p. $175-195$.

Van Houten, F.B., 1973, Origin of red beds: A review: Ann. Rev. Earth and Planet. Sci., v. l, p. 39-61.

everka, J. and Thomas, P., 1977, A study of variable features on Mars during the Viking primary mission: J. Geophys. Res., v. 82, 28, p. 4167-4187.

Walker, T.R., 1967, Formation of Red Beds in modern and ancient deserts: Bull. Geol. Soc. America, v, 78, p. 353-368.

Walker, T.R., 1979, Red color in dune sand, in McKee. E.D., (ed.), A study of global sand seas: Geol. Surv, Prof. Pap. 1052, p. 61-81.

Wendorf, F., Schild, R., Said, R., Haynes, C.V., Gautier, A. and Kobusiewicsz, M.. 1976. The prechistory of the Egyptian Sahara: Science, ve 193, 4248, p. 103-114.

Whitney, M.1. 1978. The role of vorticity in developing lineation by wind erosion: Bull. Geol. Soc. America, v, $89,1,0,1-18$.

ABOUT THE AUTHOR: Egyptian-born Farouk El Baz is one of the Arab world's best known scientists. Currently Research Director at the Center for Earth and Planetary Studies in the National Air and Space Museum of the Smithsonian Institution, Washington, D.C., he has been acting as science adviser to President Anwar Sadat of Egypt since 1978. Dr. El-Baz has worked with Bellcomm and Bell Laboratories in Washington as Supervisor of Lunar Science Planning and of Lunar Exploration, has served as Principal Investigator for Earth Observations and Photography on the Apollo-Soyuz mission (1975), has taught geology at the University of Heidelberg, West Germany, and has explored for oil in the Gulf of Suez with the Exploration Department of Pan AmericanUAR Oil Company. He is a recipient of NASA's Exceptional Scientific Achievement Medal.

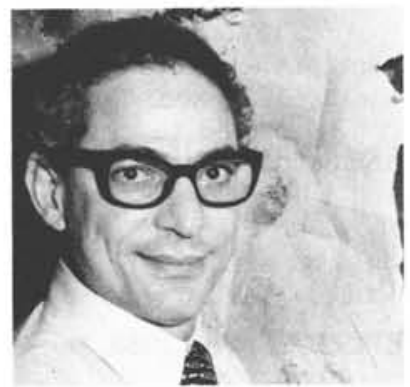

